\title{
Comparative analysis of the relative growth of Uca rapax (Smith) (Crustacea, Ocypodidae) from two mangroves in São Paulo, Brazil
}

\author{
Daniela da Silva Castiglioni ${ }^{1} \&$ Maria Lucia Negreiros-Fransozo ${ }^{1,2}$
}

\author{
${ }^{1}$ NEBECC, Group of Studies on Crustacean Biology, Ecology and Culture. \\ 2 Departamento de Zoologia, Instituto de Biociências, Universidade Estadual Paulista. Caixa Postal 510, \\ 18618-000 Botucatu, São Paulo, Brasil. E-mail: danielacastiglioni@yahoo.com.br; mlnf@ibb.unesp.br
}

\begin{abstract}
A study on the relative growth of two populations of Uca rapax (Smith, 1870) was performed primarily to determine the size at onset sexual maturity. The species was sampled monthly in Itamambuca

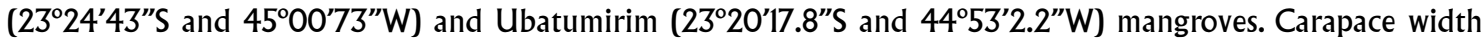
$(C W)$ and length $(C L)$, abdomen width $(A W)$, major cheliped propodus length (PL) and height (PH) for each sex, and gonopod length $(\mathrm{GL})$ for males were measured with a calliper $(0.01 \mathrm{~mm})$. Allometric analyses were used to estimate size at maturity. The relationships that most precisely indicated the size at onset of sexual maturity were AW vs. CW, for females and PL vs. CW, for males. Males and females are mature, respectively at 15.2 and $12.1 \mathrm{~mm}$ $\mathrm{CW}$ in samples from Itamambuca and 13.5 and $11.2 \mathrm{~mm} \mathrm{CW}$ in samples from Ubatumirim mangrove. Positive allometric growth of females abdominal width is likely related to the incubation process, while positively allometry growth of male's cheliped almost certainly relates to reproductive behaviour.
\end{abstract}

KEY WORDS. Allometric growth, morphologic maturity.

RESUMO. O estudo do crescimento relativo foi utilizado para determinar quais dimensões evidenciam melhor a maturidade sexual morfológica de Uca rapax (Smith, 1870). Os caranguejos foram coletados mensalmente nos

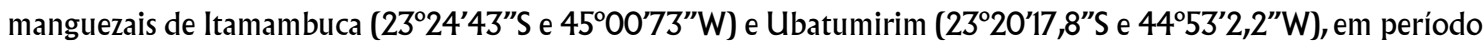
de maré baixa. Os caranguejos de ambos os sexos foram mensurados com um paquímetro $(0,01 \mathrm{~mm})$ quanto à largura da carapaça (LC), comprimento da carapaça (CC) e largura do abdome (LA). Nos machos mensurou-se ainda o comprimento e altura do própodo do quelípodo maior ( $C P Q$ e $A P Q)$ e comprimento do gonopódio (CG) e, no caso das fêmeas, comprimento e altura do própodo do quelípodo direito ( $C P Q$ e $A P Q)$. As análises alométricas foram utilizadas para estimar o tamanho da maturidade sexual morfológica. As relações que melhor evidenciaram o tamanho da maturidade foram LA vs. LC para fêmeas e CPQ vs. LC para machos. Machos e fêmeas estão maduros morfologicamente, respectivamente com 15,2 e 12,1 mm de LC em Itamambuca e 13,5 e 11,2 $\mathrm{mm}$ de LC no manguezal do rio Ubatumirim. O crescimento alomético positivo da largura do abdomen de fêmeas está relacionado com o processo de incubação, enquanto a alometria positiva do quelípodo dos machos pode estar relacionada ao comportamento reprodutivo.

PALAVRAS CHAVE. Crescimento alométrico, maturidade morfológica, manguezais.

In Brazilian coast, Melo (1996) recognized 10 species of genus Uca: U. burgesi Holthuis, 1967; U. cumulanta Crane, 1943; U. leptodactyla Rathbun, 1989; U. maracoani (Latreille, 1802-1803); U. mordax (Smith, 1870); U. thayeri Rathbun, 1900; U. uruguayensis Nobili, 1901; U. victoriana von Hagen, 1987 and $U$. vocator (Herbst, 1804). Except $U$. cumulanta and $U$. victoriana, all other species occur in littoral of São Paulo. The fiddler crab $U$. rapax is one of the most abundant species of genus Uca inhabiting mud galleries and muddy sand in tropical and subtropical mangroves. The species is distributed from Florida, through the Gulf of Mexico, Antilles, Venezuela and Brazil (from Pará to Santa Catarina) (Melo 1996). These crabs show sexual dimorphism, males have a single developed cheliped and females have both of them small and symmetrics.

Patterns of somatic growth and maturation size are important attributes in crustaceans for a better comprehension of population and reproductive biology. Crustacean growth is discontinuous, and throughout this process, some body dimensions have different growth comparing to others. HARTNOLL (1978) reported that individual variation in the standard growth of some organs or body dimensions, between individuals of each sex in the same species or in different species, have

Revista Brasileira de Zoologia 21 (1): 137-144, março 2004 
a biological significance. In Brachyura the most evident changes appear in the cheliped, abdomen and pleopods of both sexes during the transition from juvenile to adult stages.

Huxley (1924a, b, 1927) and Сотт (1929) were the first authors to study the relative growth in Ocypodidae. Subsequently, BARNES (1968) studied several Ocypodidae crabs; HALEY (1969, 1973), studied growth in Ocypode quadrata (Fabricius, 1787) and O. ceratophthalmus (Pallas); Frith \& BRunenmeIster (1983) studied the cheliped allometric level of four species of genus Uca; Colby \& Fonseca (1984), von Hagen (1987), Fransozo et al. (2002), Masunari \& Swiech-Ayoub (2003) and NegreirosFransozo et al. (2003) studied, respectively, Uca pugilator (Bosc, 1802), U. tangeri (Eydoux, 1835), Ocypode quadrata, U. leptodactyla and $U$. thayeri. However, the studies on allometry in brachyurans, especially those related to genus $U c a$, have concentrated on detecting species-specific or sex-specific growth ratios of selected appendages and body part dimensions (BARnes 1968, Miller 1973). In general, few papers have addressed intraspecific variation of relative growth in Brachyura, although Teissier (1960) conducted some studies to better understand regional populations and forms.

Due to ecological importance of $U$. rapax as a recycler of organic matter, this study has the aim to determine the body dimensions that best indicate maturity in $U$. rapax and to see how morphometric relationships used in these analysis varied in each life stage and two mangroves dominated regions in northern São Paulo, Brazil.

\section{MATERIAL AND METHODS}

Over a one year period, crabs were collected monthly in the mangroves of the Cavalo River $\left(23^{\circ} 24^{\prime} 43^{\prime \prime} S\right.$ and $\left.45^{\circ} 00^{\prime} 73^{\prime \prime} \mathrm{W}\right)$ and Ubatumirim River $\left(23^{\circ} 20^{\prime} 17,8^{\prime \prime} \mathrm{S}\right.$ and $44^{\circ} 53^{\prime} 22^{\prime \prime} \mathrm{W}$ ) both located in the city of Ubatuba (SãoPaulo), using the procedure of capture per unit effort (cpue) by two peoples, during 30 minutes in low tide.

Body dimensions were measured with precision callipers, with an accuracy of $0.01 \mathrm{~mm}$. Measurements included carapace width (CW), carapace length (CL), abdomen width (AW) of the fifth somite, propodus length $(\mathrm{PL})$, propodus height $(\mathrm{PH})$ for each sex and gonopod length (GL) for males. Crabs with damaged carapace or incomplete chelipeds were not considered in the analyses.

The software Mature I (SOMERTON 1980) was used to determine morphological maturity size of males and females, in order to distinguish immature from adult crabs by relative growth regression analysis.

These analysis were based on biometric data, observing changes in relative growth of some body parts related to others, inferring the inflexion point of critical moult. All analyses were based on the allometric function $\left(y=a x^{b}\right)$ (HuXLey 1950). Carapace width (CW) was used as independent variable (x) whereas the other body dimensions were considered dependent variables (y). The slope " $b$ " of the equation is the allom- etric constant that express the analogy between two variables, then it is used to determine a growth coefficient for males and females. For instance $b>1$ indicates positive allometric growth, $\mathrm{b}=1$ isometric growth and $\mathrm{b}<1$, negative allometric growth (Teissier 1960, Hartnoll 1982). The " $\mathrm{b}$ " value was tested by " $\mathrm{t}$ " student test $\left(\mathrm{H}_{0}: \mathrm{b}=1 ; \alpha=5 \%\right)$. For each relation, a power function was obtained and linearized by $\log (\log y=\operatorname{loga}+$ blogx) for immature and adult crabs. To test the equality among slopes and intercepts of straight lines of the life stages (immature and adult) and also among straight lines obtained for the populations of two mangroves habitats was applied a covariance analysis (ANCOVA, $\alpha=5 \%$ ) (ZAR 1996).

\section{RESULTS}

The relative growth analysis were performed on 587 and 598 crabs from Itamambuca and Ubatumirim, respectively. The sex ratio was $1: 1$ in both sites. The male carapace width ranged of 4.3 to $28.3 \mathrm{~mm}(15.2 \pm 4.6)$ and females of 4.3 to $27.3 \mathrm{~mm}$ $(13.8 \pm 4.6)$ in Itamambuca; while in Ubatumirim the males showed a size amplitude of 4.0 to $24.2 \mathrm{~mm}(13.5 \pm 4.8)$ and the females of 4.0 to $22.0 \mathrm{~mm}(12.9 \pm 4.4)$.

The relationships among the body dimensions obtained for each sex and life stage of $U$. rapax at the Itamambuca and Ubatumirim mangroves are presented on tables I and II, respectively.

The values obtained by the Mature I analysis (SOMERTON 1980) at the morphological sexual maturity of crabs for the Itamambuca mangrove, ascertained that 50\% males are mature with $15.2 \mathrm{~mm} \mathrm{CW} \mathrm{(F=82,67;} \mathrm{p}<0,05)$ (Fig. 6) and the females are morphological matures with about $12.1 \mathrm{~mm} \mathrm{CW}$ (50\% females; $\mathrm{F}=224,72 ; \mathrm{p}<0,05$ ) (Fig. 7). At the Ubatumirim mangrove, 50\% males showed morphological mature with $13,5 \mathrm{~mm}$ CW ( $\mathrm{F}=205,77 ; \mathrm{p}<0,05 ;$ Fig. 6). However, 50\% females reached their maturity at about $11.2 \mathrm{~mm} \mathrm{CW}(\mathrm{F}=156,33$; $\mathrm{p}<0,05$; Fig. 7).

Growth of the $U$. rapax from Itamambuca mangrove showed negative allometry to both sexes for the CL vs. CW relationship, with exception of adult females, that exhibited isometry (Tab. I). Juveniles of both sexes showed negative allometry whereas adults presented isometry at the Ubatumirim mangrove (Tab. I).

The abdominal width growth (AW) usually characterises a well-defined sexual dimorphism in Brachyura. For the relationship AW vs. CW, juvenile and adult females presented positive allometry at the two mangroves (Fig. 8), indicating a high growth ratio when juvenile (Tabs I and II). However, juvenile and adult males in Itamambuca presented a positive and negative allometry, respectively. In Ubatumirim, juvenile males presented a isometry and adults negative allometry.

For the relationship PL $v s$. CW, in both mangroves, males presented positive allometry, in which the changes in chelipeds allometry level were more evident between juvenile and adult (Tabs I and II) (Fig. 9). However, females presented a negative allometry in this relationships in both mangroves (Tabs I and II). 
Table I. Uca rapax from Itamambuca mangrove. Results of the regression analysis of the carapace morphometric relations, based on the carapace width (CW) as independent variable.

\begin{tabular}{|c|c|c|c|c|c|c|c|}
\hline Variable & Sex & $\mathrm{N}$ & Power function $y=a x^{b}$ & Linear equation $\log y=\log a+b \log x$ & $\overline{r^{2}}$ & Allometric level & $\mathrm{t}(\mathrm{b}=1)$ \\
\hline \multirow{4}{*}{$\mathrm{CL}$} & $\mathrm{JM}$ & 150 & $\mathrm{CL}=0.746 \mathrm{CW}^{0.96}$ & $\log C L=-0.12+0.96 \mathrm{LogCW}$ & 0.96 & - & $2.89^{*}$ \\
\hline & AM & 143 & $C L=0.846 C W^{0.91}$ & $\log C L=-0.07+0.91 \mathrm{Log} C W$ & 0.94 & - & $4.31^{*}$ \\
\hline & $J \mathrm{~F}$ & 101 & $C L=0.840 C W^{0.91}$ & $\log C L=-0.07+0.91 \mathrm{LogCW}$ & 0.94 & - & $3.57^{*}$ \\
\hline & $\mathrm{AF}$ & 193 & $C L=0.711 C W^{0.98}$ & $\log C L=-0.14+0.98 \mathrm{Log} C W$ & 0.98 & 0 & $1.06 \mathrm{~ns}$ \\
\hline \multirow{4}{*}{ AW } & JM & 147 & $\mathrm{AW}=0.203 \mathrm{LC}^{1.10}$ & LogAW $=-0.69+1.10$ LogCW & 0.92 & + & $-3.76^{*}$ \\
\hline & AM & 142 & $\mathrm{AW}=0.409 \mathrm{LC}^{0.83}$ & $\log A W=-0.38+0.83 \mathrm{Log} C W$ & 0.72 & - & $3.84^{*}$ \\
\hline & $\mathrm{JF}$ & 98 & $\mathrm{AW}=0.091 \mathrm{LC}^{1.67}$ & $\log A W=-1.03+1.67 \log C W$ & 0.90 & + & $11.77^{*}$ \\
\hline & $\mathrm{AF}$ & 184 & $\mathrm{AW}=0.323 \mathrm{LC}^{1.23}$ & $\log A W=-0.49+1.23 \mathrm{Log} C W$ & 0.90 & + & $-7.55^{*}$ \\
\hline \multirow{3}{*}{ PL } & JM & 140 & $\mathrm{PL}=0.253 \mathrm{CW}^{1.55}$ & $\log P L=-0.59+1.55 \mathrm{Log} C W$ & 0.96 & + & $-20.20^{\star}$ \\
\hline & AM & 136 & $\mathrm{PL}=0.285 \mathrm{CW}^{1.52}$ & $\log P L=-0.54+1.52 \mathrm{Log} C W$ & 0.82 & + & $-8.67^{*}$ \\
\hline & $\mathrm{F}(\mathrm{ns})$ & 287 & $\mathrm{PL}=0.435 \mathrm{CW}^{0.95}$ & $\log P L=-0.36+0.95 \mathrm{Log} C W$ & 0.96 & - & $4.09^{*}$ \\
\hline \multirow{3}{*}{$\mathrm{PH}$} & JM & 147 & $\mathrm{PH}=0.151 \mathrm{CW}^{1.45}$ & $\mathrm{Log} P H=-0.82+1.45 \mathrm{LogCW}$ & 0.95 & + & $-16.80^{*}$ \\
\hline & AM & 138 & $\mathrm{PH}=0.278 \mathrm{CW}^{1.22}$ & $\log P H=-0.55+1.22 \mathrm{LogCW}$ & 0.82 & + & $-4.65^{\star}$ \\
\hline & $\mathrm{F}(\mathrm{ns})$ & 287 & $\mathrm{PH}=0.153 \mathrm{CW}^{0.91}$ & $\log P H=-0.81+0.91 \mathrm{Log} C W$ & 0.95 & - & $6.92^{*}$ \\
\hline \multirow{2}{*}{$\mathrm{GL}$} & JM & 147 & $\mathrm{GL}=0.178 \mathrm{CW}^{1.30}$ & $\log G L=-0.74+1.30 \mathrm{LogCW}$ & 0.91 & + & $-8.98^{*}$ \\
\hline & MA & 140 & $\mathrm{GL}=0.565 \mathrm{CW}^{0.86}$ & $\operatorname{LogGL}=-0.24+0.86 \mathrm{Log} C W$ & 0.80 & - & $3.59^{*}$ \\
\hline
\end{tabular}

$n s: p>0.05$, there is no statistical difference between juvenile and adult straight lines. $\left.{ }^{*}\right)$ Test t Student $(p<0.05)($ Ho: $b=1)$. (AW)abdomen width, (PL)major cheliped propod length, $(\mathrm{PH})$ major chelar propodus height, $(\mathrm{GL})$ gonopod length, $\left(\mathrm{r}^{2}\right)$ regression coefficient, $(\mathrm{JM})$ juvenile male, (AM)adult males, (JF)juvenile female, AF)adult female, (N)number of specimens, (0)isometry, (-)negative allometry and (+)positive allometry.

Table II. Uca rapax from Ubatumirim mangrove. Results of the regression analysis of the carapace morphometric relations, based on the carapace width (CW) as independent variable.

\begin{tabular}{|c|c|c|c|c|c|c|c|}
\hline Variable & Sex & $\mathrm{N}$ & Power function $y=a x^{b}$ & Linear equation $\log y=\log a+\log x$ & $\mathrm{r}^{2}$ & Allometric Level & $t(b=1)$ \\
\hline \multirow{4}{*}{$\mathrm{CL}$} & $\mathrm{JM}$ & 125 & $\mathrm{CL}=0.848 \mathrm{CW}^{0.88}$ & $\log C L=-0.07+0.88 \mathrm{LogCW}$ & 0.97 & $\overline{-}$ & $7.73^{*}$ \\
\hline & AM & 174 & $C L=0.643 C^{1.00}$ & $\log C L=-0.19+1.00 \mathrm{Log} C W$ & 0.97 & 0 & -0.19 \\
\hline & $\mathrm{JF}$ & 98 & $C L=0.865 C W^{0.88}$ & $\log C L=-0.06+0.88 \mathrm{Log} C W$ & 0.96 & - & $6.81^{*}$ \\
\hline & $\mathrm{AF}$ & 201 & $C L=0.657 \mathrm{CW}^{1.00}$ & $\log C L=-0.18+1.00 \mathrm{Log} C W$ & 0.97 & 0 & $-0.28 n s$ \\
\hline \multirow{4}{*}{ AW } & JM & 124 & $\mathrm{AW}=0.262 \mathrm{CW}^{0.99}$ & LogAW $=-0.58+0.99 \operatorname{LogCW}$ & 0.85 & 0 & $0.09 \mathrm{~ns}$ \\
\hline & AM & 169 & $\mathrm{AW}=0.341 \mathrm{CW}^{0.88}$ & $\log A W=-0.46+0.88 \mathrm{Log} C W$ & 0.97 & - & $4.14^{*}$ \\
\hline & $\mathrm{JF}$ & 97 & $\mathrm{AW}=0.147 \mathrm{CW}^{1.45}$ & $\log A W=-0.83+1.45 \mathrm{Log} C W$ & 0.91 & + & $-9.63^{*}$ \\
\hline & $\mathrm{AF}$ & 198 & $\mathrm{AW}=0.254 \mathrm{CW}^{1.31}$ & $\log A W=-0.59+1.31 \mathrm{Log} C W$ & 0.89 & + & $-9.79 *$ \\
\hline \multirow{3}{*}{ PL } & JM & 124 & $\mathrm{PL}=0.329 \mathrm{CW}^{1.43}$ & LogCPL $=-0.48+1.43 \mathrm{LogCW}$ & 0.97 & + & $-18.50^{*}$ \\
\hline & AM & 151 & $\mathrm{PL}=0.109 \mathrm{CW}^{1.86}$ & $\log C P L=-0.96+1.86 \mathrm{Log} C W$ & 0.92 & + & $-19.56^{*}$ \\
\hline & $\mathrm{F}(\mathrm{ns})$ & 298 & $\mathrm{PL}=0.472 \mathrm{CW}^{0.91}$ & $\log C P L=-0.32+0.91 \log C W$ & 0.97 & - & $9.86^{*}$ \\
\hline \multirow{4}{*}{$\mathrm{PH}$} & JM & 125 & $\mathrm{PH}=0.232 \mathrm{CW}^{1.25}$ & $\mathrm{Log} P H=-0.63+1.25 \mathrm{Log} C W$ & 0.96 & + & $-10.89^{*}$ \\
\hline & AM & 158 & $\mathrm{PH}=0.204 C \mathrm{~W}^{1.31}$ & $\log P H=-0.68+1.31 \operatorname{LogCW}$ & 0.90 & + & $-9.11^{*}$ \\
\hline & $J F$ & 98 & $\mathrm{PH}=0.315 \mathrm{CW}^{0.57}$ & $\log P H=-0.50+0.57 \log C W$ & 0.70 & - & $10.99^{*}$ \\
\hline & $\mathrm{AF}$ & 192 & $\mathrm{PH}=0.156 \mathrm{LC}^{0.89}$ & $\log P H=-0.80+0.89 \log L C$ & 0.85 & - & $3.92^{\star}$ \\
\hline \multirow{2}{*}{ GL } & $\overline{J M}$ & 123 & $\mathrm{GL}=0.150 \mathrm{CW}^{1.36}$ & $\operatorname{LogGL}=-0.82+1.36 \mathrm{LogCW}$ & 0.88 & + & $-10.72^{*}$ \\
\hline & AM & 165 & $\mathrm{GL}=0.369 \mathrm{CW}^{0.99}$ & $\operatorname{LogGL}=-0.43+0.99 \mathrm{LogCW}$ & 0.80 & 0 & $0.02 \mathrm{~ns}$ \\
\hline
\end{tabular}

$n s: p>0.05$, there is no statistical difference between juvenile and adult straight lines. $\left.{ }^{*}\right)$ Test t Student $(p<0.05)($ Ho: $b=1) .($ AW $)$ abdomen width, (PL)major cheliped propod length, (PH)major chelar propodus height, $(\mathrm{GL})$ gonopod length, $\left(\mathrm{r}^{2}\right)$ regression coefficient, (JM)juvenile male, (AM)adult males, (JF)juvenile female, (AF)adult female, (N)number of specimens, 0)isometry, (-) negative allometry and (+)positive allometry. 

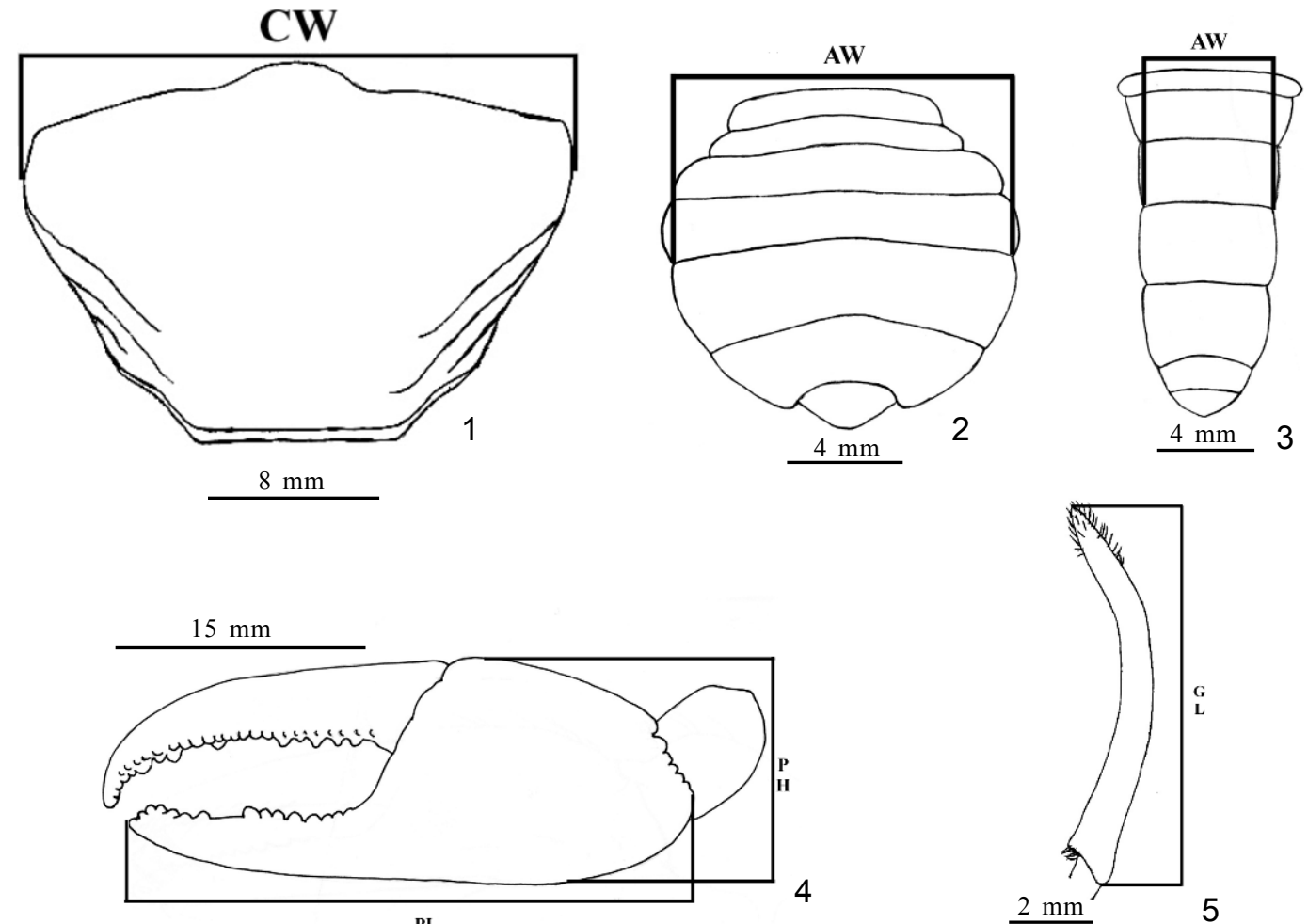

PL

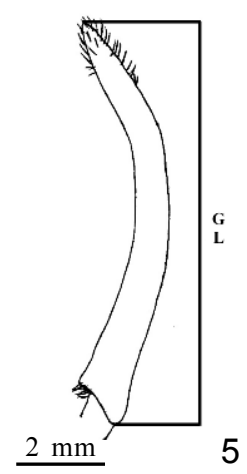

Figures 1-5. Uca rapax, dimensions used in the morphometric analysis: (1) dorsal view of carapace, (2) female abdomen, (3) male abdomen, (4) gonopod, (5) lateral view of the cheliped major.
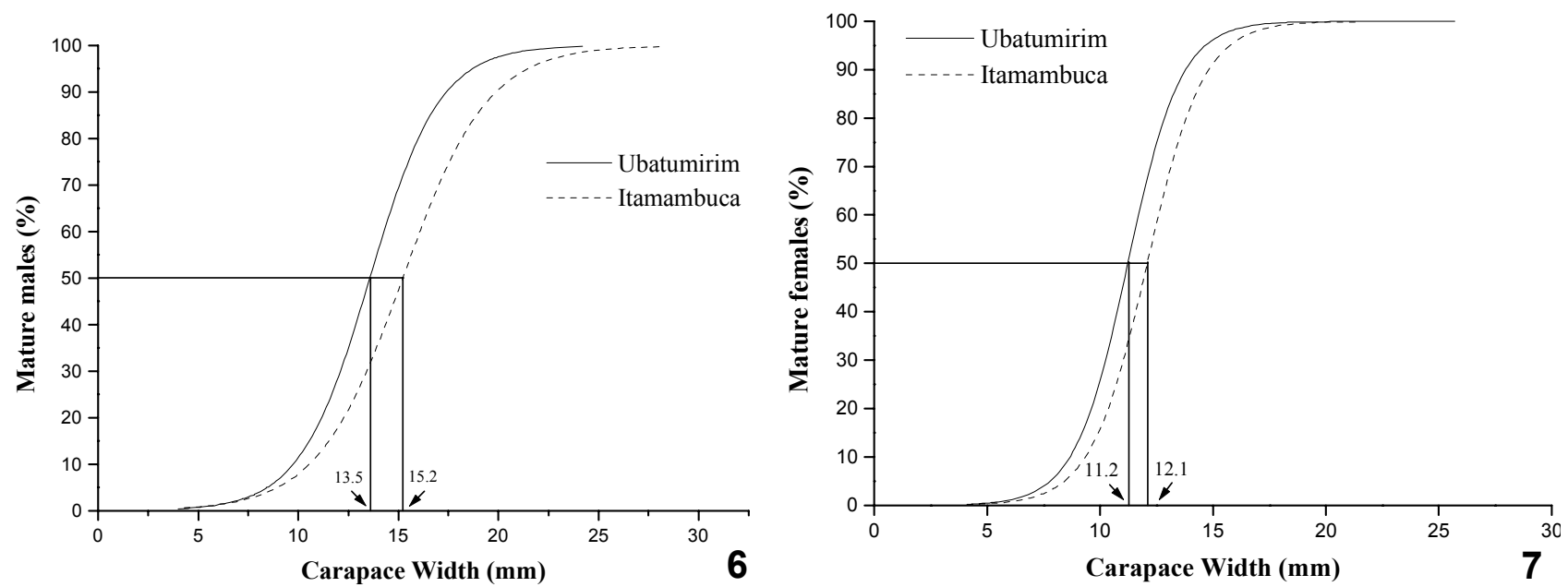

Figures 6-7. Uca rapax, sexual maturity at $50 \%$ for (6) males and (7) for females. (AW) abdomen width, (CW) Carapace width, (PL) cheliped propod length.

Males and females, in both mangroves, presented positive and negative allometry, respectively, for the $\mathrm{PH} v s$. CW relationship (Tabs I and II).
The gonopods growth was distinct between phases at the two studied mangroves, but juvenile males presented a larger growth than adults (Tabs I and II).

Revista Brasileira de Zoologia 21 (1): 137-144, março 2004 

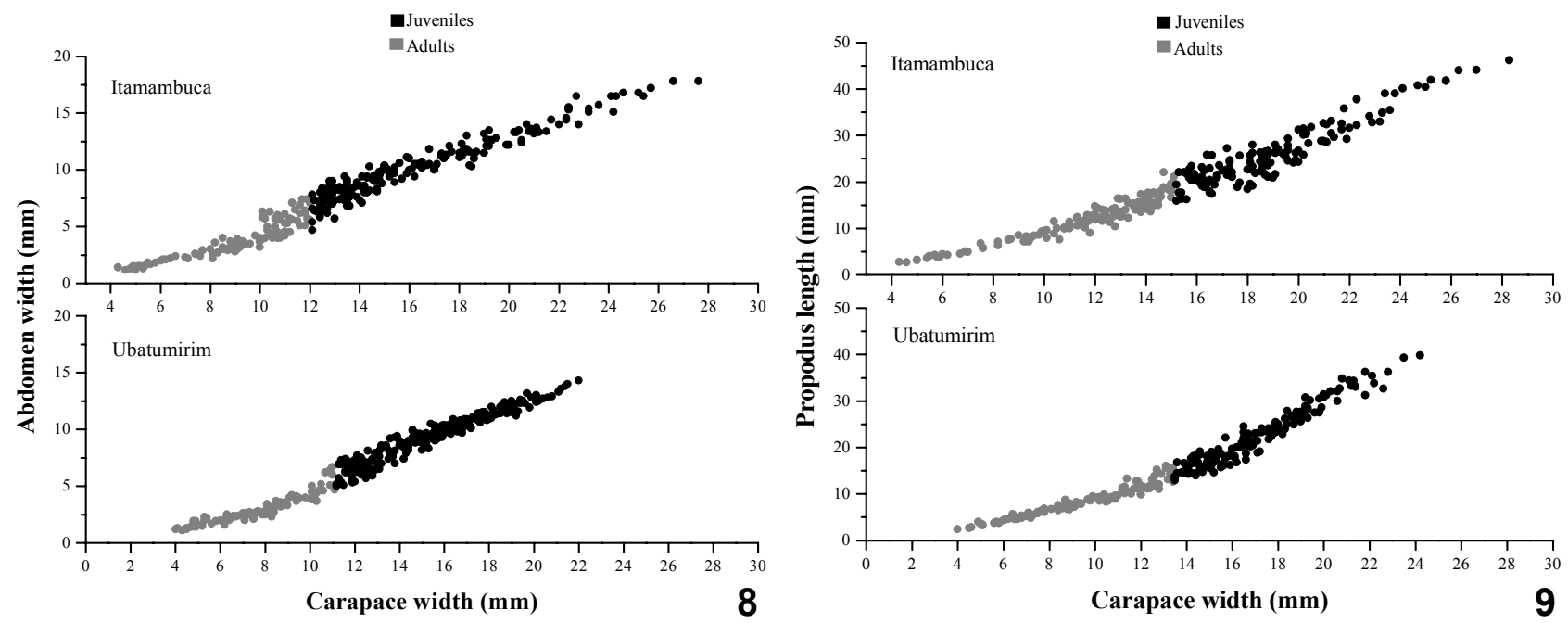

Figures 8-9. Uca rapax, morphometric relation between: (8) carapace width and abdomen width, (9) carapace width and propodus length.

Only the relationships AW vs. CW for females and PL vs. $\mathrm{CW}$ for males, indicates evidence of maturity for both populations.

By means of covariance analysis, it can be ascertained that relative growth pattern differ significantly $(\mathrm{p}<0.05)$ between juvenile and adult for almost all the studied relationship, except to the PL $v s$. CW and PH vs. CW from Itamambuca females and PL $v s$. CW from females of Ubatumirim mangrove. The same analysis was employed to compare the relationships between the mangroves pertaining the same development phase, in which the results showed statistical differences $(\mathrm{p}<$ 0.05 ) for the majority of the cases. Exception were obtained in the relationships AW vs. CW and PL vs. CW for adult and juvenile females, respectively and GL $v s$. CW for juvenile males.

\section{DISCUSSION}

Variations on crab size observed in the present study are commonly related to phenotypic plasticity typically influenced by environmental factors as photoperiod, temperature, rainfall, food resource and others (CAMPBELl \& Eagles 1983). According to HinEs (1989), variations in the moult increment or in the number of moults before puberty can affect crab size and consequently determine differences in sizes at the puberty moult. According to Hartnoll (1982), the onset of sexual maturity represents a very important biological event characterised by a set of morphological and physiological transformations what promote habitat and/or behavioural changes.

In general, males of crab species are considered morphologically mature once they are able to retain females during preand postcopulatory guarding and transfer successfully sperm to females. The latter, however, reach maturity when they are able to mate and spawn (Hartnoll 1969, Pinheiro \& Fransozo 1998).
The carapace width has been generally considered an independent variable in brachyuran morphometric studies because it shows few physiological changes throughout a crab's life history. The relationship between carapace length and width, however, is not appropriate to express one biological alterations that occur in crab's life (SANTOs et al. 1995).

For some brachyuran species, a few organs show a remarkable variation on allometric levels during a pubertal period, mainly the cheliped, abdomen and pleopod setae. The cheliped dimensions growth is especially outstanding for males because it promotes wins during intra and interspecific conflict, agnostic behaviour, display and courtship. It is also advantageous during thereproductive period, when males fight for females that will be subsequently handled by chelipeds during mating (HaRTNoll 1968, 1982, Warner 1970, PinHeiro \& Fransozo 1999).

Female crabs show frequently an increase in abdomen width that provides a chamber where the egg mass is attached to the pleopods and protected during incubation. The male abdomen sustains and protects two pairs of pleopods that are responsible for transferring sperm during mating. Their growth, in most of brachyuran species, is isometric throughout male life history. The female abdomen, however, shows a noticeable positive allometry (HARTNOLL 1982). This was also verified in other ocypodid such as those studied by Fransozo et al. (2002), Masunari \& Swiech-Ayoub (2003) and Negreiros-Fransozo et al. (2003) and U. rapax in the present paper.

Species of the genus $U c a$ are characterised by remarkable sexual dimorphism; while males have one extremely developed, asymmetric cheliped, females have two small symmetric chelipeds. Females use both to carry substratum particles to their mouthparts, but males use only the small to feed. The largest 
is used, by males, in terrestrial fights and courtship (CHRIsTY \& SALMON 1984). The males of $U$. rapax showed a positive allometry in PL $v s$. CW relationship, being that the cheliped growth was more accented after puberty moult for crabs from both mangroves.

The fiddler crab $U$. rapax showed an allometric pattern similar to that found by Negreiros-Fransozo et al. (2003) for $U$. thayeri population from the estuary formed by the rivers Comprido and Escuro (Ubatuba) and Masunari \& Swiech-Ayoub (2003) for U. leptodactyla from Santa Catarina littoral.

The relative growth rate of $U$. rapax was similar at both mangroves. However, the size of crabs reaching at puberty moult was different between sites. This difference can be related to food availability, substratum changes and population density (Hines 1989). Analysis on organic matter quantity and substratum texture will elucidate this hypothesis, since species of genus $U c a$ feed on organic particles presented in sediment. According to WenNer et al. (1974), the food availability can promote differences on the maximum size in which population can achieve and consequently in the size at puberty moult, because the more available is the resource, the faster is crab growth. Colpo \& Negreiros-Fransozo (2003) ascertained that ovigerous female of $U$. vocator population from Itamambuca, Indaiá and Itapanhaú mangroves showed different sizes in account of differential food resource between these localities.

VON HAGEN (1987) verified that two population of $U$. tangeri living at distinct areas (sand and mud) showed different allometry levels. The population inhabiting sand showed lower allometry, trying other alternatives to compensate the nitrogen scarcity.

Sizes that indicate sexual maturity were smaller for females than for males from both mangroves. It happens because females spend most of their energy with reproduction and hence they become smaller than males (WARNER 1967, Diaz \& Conde 1989, Christy \& SALMON 1984). This difference in the size at puberty moult between sex is very common and it has been verified for some other Brachyura species: Ocypode ceratophthalmus studied by Haley (1973), Sesarma reticulatum (Say, 1817) studied by SeIPLE \& SALMON (1987), Callinectes ornatus Ordway, 1863 studied by HaEfner (1990), Arenaeus cribrarius (Lamarck, 1818) studied by Pinheiro \& Fransozo (1998), Perisesarma guttatum (A. Milne Edwards, 1869) studied by Flores et al. (2002), U. leptodactyla studied by Masunari \& SWIECH-Ayoub (2003) and $U$. thayeri studied by Negreiros-Fransozo et al. (2003).

An isolated analysis on relative growth cannot be used as a single criterion to define the reproduction beginning for some Brachyura, because sometimes the morphological maturity is not coincident with physiological maturity (GonzÁLEZGuRRIARÁN \& Freire 1994). Thus, micro or macroscopic analysis on gonad of each sex may further define the point at which the crab is able to copulate.

Variations on growth patterns observed in these populations of $U$. rapax seem to have an adaptive meaning probably associated with reproductive strategies. The excessive growth shown by male chelipeds must be related to reproductive behaviour, including courtship and agonistic interactions with other males on territorial fights (Crane 1975, Christy 1978, 1983, Christy \& Salmon 1984, Backwell et al. 2000). The positive allometry shown by female abdomen is related to egg incubation (HaRTNOLL 1974). In spite of information presenting on this paper, posterior studies based on adaptation could bring up a better comprehension of these changes (STEARns \& Koella 1986).

\section{ACKNOWLEDGEMENTS}

To the "Fundação de Amparo à Pesquisa no Estado de São Paulo" for the fellowship to the first author (\#01/01810-9) and to NEBECC colleagues for their help during field and laboratory activities. This work was accomplished according to state and federal laws concerning to wild animal samplings.

\section{REFERENCES}

Backwell, P.R.Y.; J.H. Christy; S.R. Telford; M.D. Jennions \& N. I. Passmore. 2000. Dishonest signalling by a fiddler crab. Proceedings of the Royal Society of London 267 (B): 1-6. BARNES, R.S.K. 1968, Relative carapace and chela proportions in some ocypodid crabs (Brachyura, Ocypodidae). Crustaceana, Leiden, 14: 131-136.

Campbell, A. \& M.D. Eagles. 1983. Size at maturity and fecundity of rock crabs, Cancer irroratus, from the Bay of Fundy and southwestern Nova Scotia. Fishery Bulletin, Washington, 81 (2): 357-362.

Christy, J.H. 1978. Adaptive significance of reproductive cycles in the fiddler crab Uca pugilator: A hypothesis. Science, Washington, 199: 453-455.

-1983. Female choice in the resource-defence mating system of the sand fiddler crab Uca pugilator. Behavioral Ecology and Sociobiology, Boston, 12: 169-180.

Christy, J.H. \& M. SAlmon. 1984. Ecology and evolution of mating systems of fiddler crabs (Genus Uca). Biological Review, Cambridge, 59: 483-509.

Colby, D. \& M. Fonseca. 1984. Population dynamics, spatial dispersion and somatic growth of the sand fiddler crab Uca pugilator. Marine Ecology Progress Series, Amelinghausen, 16: 262-279.

Colpo, K.D. \& M.L. Negreiros-Fransozo. 2003. Reproductive output of Uca vocator(Herbst, 1804) (Brachyura, Ocypodidae) from three subtropical mangroves in Brazil. Crustaceana, Leiden, 76 (1): 1-11.

Cotт, H.B. 1929. Observations on the natural history of the racing-crab Ocypoda ceratophthalmus, from Beira. Proceedings of the Zoological Society of London 4: 755-765.

CRANE, J. 1975. Fiddler crabs of the world Ocypodidae: genus Uca. New Jersey, Princeton University Press, 736p.

Diaz, H. \& J.E. Conde. 1989. Population dynamics and life history of the mangrove crab Aratus pisonii (Brachyura, 
Grapsidae) in a marine environment. Bulletin of Marine Science, Miami, 45 (1): 14-163.

Flores, A.A.V.; J. Saraiva \& J. Paula. 2002. Sexual maturity, reproductive cycles and juvenile recruitment of Perisesarma guttatum (Brachyura, Sesarmidae) at Ponta Rasa mangrove swamp, Inhaca Island, Mozambique. Journal of Crustacean Biology, San Antonio, 22 (1): 143-156.

Fransozo, A.; M.L. Negreiros-Fransozo \& G. Bertini. 2002. Morphometric study of the ghost crab Ocypode quadrata (Fabricius, 1887) (Brachyura, Ocypodidae) from Ubatuba, São Paulo, Brazil, p. 189-195. In: E. Escobar-Briones \& F. Alvarez (Eds). Modern Approaches to the study of Crustacea. New York, Ed. Kluwer Academic/Plenum Publishers, vol. 1, XIX+355p.

Frith, D.W. \& S. BRunenmeister. 1983. Fiddler crab (Ocypodidae: Genus Uca) Size, allometry and male major mhela handedness and morphism on a Thailand mangrove Shore. Punket Marine Biological Center. Research Bulletin, New South Wales, 29: 1-16.

GonzÁlez-Gurriarán, E. \& J. Freire. 1994. Sexual maturity in the velvet swimming crab Necora puber (Brachyura: Portunidae): morphometric and reproductive analyses. Journal of Marine Science, Dauphin Island, 51: 133-145.

HaEfNer JR., J.A. 1990. Morphometry and size at maturity of Callinectes ornatus (Brachyura, Portunidae) in Bermuda. Bulletin of Marine Science, Miami, 46 (2): 274-286.

HaLEY, S.R. 1969. Relative growth and sexual maturity of the texas ghost crab, Ocypode quadrata (Fabr) (Brachyura, Ocypodidae). Crustaceana, Leiden, 17 (3): 285-297.

. 1973. On the use of morphometric data as a guide to reproductive maturity in the ghost crab, Ocypode ceratophthalmus (Pallas) (Brachyura, Ocypodidade). Pacific Science, Honolulu, 27 (3): 350-362.

Hartnoll, R.G. 1968. Reproduction in the burrowing crab, Corystes cassivelaunus (Pennant, 1777) (Decapoda, Brachyura). Crustaceana, Leiden, 15: 165-170.

- 1969. Mating in the Brachyura. Crustaceana, Leiden, 16: 161-181.

- 1974. Variation in growth pattern between some secondary sexual characters in crabs (Decapoda, Brachyura). Crustaceana, Leiden, 27 (2): 151-156.

. 1978. The determination of relative growth in Crustacea. Crustaceana, Leiden, 34 (3): 281-293.

- 1982. Growth, p. 111-196. In: D.E. Buss (Ed). The Biology of Crustacea: embryology, morphology and genetics. New York, Academic Press, Inc., vol. 2, 440p.

Hines, A.H. 1989. Geographic variation in size at maturity in brachyuran crabs. Bulletin of Marine Science, Miami, 45 (2): 356-368.

HuXLEY, J.S. 1924a. The variation in the width of the abdomen in immature fiddler crabs considered in relation to its relative growth-rate. American Naturalist, Chicago, 58 (658): 468-475.

. 1924b. Constant differential growth-ratios and their significance. Nature, London, 114: 895-896.

. 1927. Further work on heterogonic growth. Biologisches Zentralblatt, Leipzig, 47: 151-163.

. 1950. Relative growth and form transformation. Proceedings of Royal Society of London 137 (B): 465-469.

Masunari, S. \& B.P. Swiech-Ayoub. 2003. Crescimento relativo de Uca leptodactyla Rathbun (Crustacea Decapoda Ocypodidae). Revista Brasileira de Zoologia, Curitiba, 20 (3): 487-491.

Melo, G.A.S. 1996. Manual de Identificação dos Brachyura (Caranguejos e Siris) do Litoral Brasileiro. São Paulo, Plêiade, 604p.

Miller, D.C. 1973. Growth in Uca. 1. Ontogeny of asymmetry in Uca pugilator (Bosc) (Decapoda, Ocypodidae). Crustaceana, Leiden, 24: 119-131.

Negreiros-Fransozo, M.L.; K.D. Colpo \& T.M. Costa. 2003. Allometric growth in the fiddler crab Uca thayeri (Brachyura, Ocypodidae) from a subtropical mangrove. Crustaceana, Leiden, 23 (2): 273-279.

Pinheiro, M.A.A. \& A. Fransozo. 1998. Sexual maturity of speckled swimming crab Arenaeus cribrarius (Lamarck, 1818) (Decapoda, Brachyura, Portunidae), in the Ubatuba littoral, São Paulo state, Brazil. Crustaceana, Leiden, 71 (6): 15-47.

Pinheiro, M.A.A. \& A. Fransozo. 1999. Reproductive behavior of the swimming crab Arenaeus cribrarius (Lamarck, 1818) (Crustacea, Brachyura, Portunidae) in captivity. Bulletin of Marine Science, Miami, 64 (2): 243-253.

Santos, S.; M.L. Negreiros-Fransozo \& A. Fransozo. 1995. Morphometric relationships and maturation in Portunus spinimanus Latreille, 1819 (Crustacea, Brachyura, Portunidae). Revista Brasileira de Biologia, Rio de Janeiro, 55 (4): 545-553.

Seiple, W.H. \& M. SAlmon. 1987. Reproductive, growth and lifehistory contrasts between two species of grapsid crabs, Sesarma cinereum and S. reticulatum. Marine Biology, Berlin, 94: 1-6.

Somerton, D. 1980. A computer technique for estimating the size of sexual maturity in crabs. Canadian Journal of Fishery and Aquatic Science, Ottawa, 37: 1488-1494.

Stearns, S.C. \& J.C. Koella. 1986. The evolution of phenotypic plasticity in life-history traits: predictions of reaction norms for age and size at maturity. International Journal of Organic Evolution, Lawrence, 40 (5): 893-913.

TeIsSIER, G. 1960. Relative growth, p. 537-560. In: T.H. WATERMAnN (Ed). The Physiology of Crustacea. New York, Academic Press, vol. 1.

von Hagen, H.O. 1987. Allometric growth in two populations of Uca tangeri from the Guadalquivir estuary (Andalusia). Investigaciones Pesqueras, Montevideo, 51 (Supl. 1): 443452.

WARNER, G.F. 1967. The life history of the mangrove tree crab, Aratus pisonii. Journal of Zoology, London, 153: 321-335. .1970. Behavior of two species of grapsid crabs during

Revista Brasileira de Zoologia 21 (1): 137-144, março 2004 
intra-specific encounters. Behaviour, Lieden, 36: 9-19. Wenner, A.M.; C. Fusaro \& A. OAten. 1974. Size at onset of sexual maturity and growth rate in crustacean populations.
Canadian Journal of Zoology, Ottawa, 52 (9): 1095-1106. ZAR, J.H. 1996. Biostatistical analysis. New Jersey, Upper Saddle River, Prentice-Hall, 662p.

Received in 04.VII.2003; accepted in 27.II.2004.

Revista Brasileira de Zoologia 21 (1): 137-144, março 2004 